\title{
UNDERSTANDING RESIDENT’'ACTIVITY SYSTEM-IMPROVING QUALITY LIFE: A CASE STUDY OF DOME POST DISASTER SETTLEMENT IN NGELEPEN SLEMAN, YOGYAKARTA
}

\author{
SYAM, Rachma Marcillia ${ }^{1^{*}}$, RATNASARI, Anisza Ratnasari ${ }^{2}$ \\ ${ }^{1,2}$ Department of Architecture and Planning, Engineering Faculty, \\ Gajah Mada University, Jalan Grafika No.2, Sinduadi, Melati, Sleman, Yogyakarta 55281 \\ Email: aniszaratnasari@yahoo.com \\ *Corresponding author: syam@ugm.ac.id
}

\begin{abstract}
House is not only functioning as a place for shelter, but also for accommodating personal and social activities of its inhabitants. Unfortunately in post quake disaster dome houses Ngelepen, Yogyakarta, the majority of the early settlers must change their behavior and habits that they used to do in their previous environment to adjust the new settlement. These happened because dome housing did not facilitate some activities whether personal or social activities within the house, therefore the activities extended to the outside of the house or even the surrounding environment. This study aims to understand the system activities on the dome house settlement Yogyakarta. In order to get detailed description, quantitative as well as qualitative approach was done through observation of the activities type, when and where the activities conducted. Data collection was done by continuous place centered behavior mapping to know how the occupants use and accommodate their behavior in certain time and specific place. The results of this study showed that daily activities on weekdays and holidays conducted by different group; children, adult and elderly, at different areas and for different type of activities in certain times. The pathways and courtyard of the house mostly used for domestic household activities and leisure as an extension of the social interaction space. In understanding the system activities that occurred, it is expected that this study can contribute to improve the quality of life of people live in a relocation settlement.
\end{abstract}

Keywords: Post-disaster dome settlement; activity system; social interaction.

\section{INTRODUCTION}

The existence of dome house settlement in Nglepen, Yogyakarta is part of donation from the help of World Association of Non Government in collaboration with the Dome for the World to help earthquake victims in Yogyakarta that happened in May 2006. The usage of dome house earthquake victims did not only happened in Indonesia but also has been done in several places around the world. Oliver (1987) mentions that house dome settlement were given Gediz earthquake victims in Kutahya, Turkey. In addition, on 1972 there had been a settlement of 500 houses with shaped igloo that is designed by the West German Bayer Corporation as a response to the earthquake that happened in Nicaragua. Unfortunately, based on previous research there is only around $30 \%$ of these houses that were inhabited since it is culturally unsuitable to the character of the local people. The same situation also happened in dome post disaster housing in Nglepen, Yogyakarta. It is a new post disaster settlement and relocated about $2 \mathrm{~km}$ from its occupants' original site. From 71 houses built, only around 20 houses (28\%) were occupied at the end of April 2007 or approximately 5 months after the complex of the dome housing is ready to be inhabited (Saraswati, 2007).
The issue that often appears in a new settlement is the gap between the user and designers (planner and architect). Design of buildings as well as site that focus more on technical matters without consideration of the needs and lifestyle of its resident can result in house or environment that less comfortable because their needs are not accommodated. The dome house are not easily compatible with the Indonesian culture, both in form and spatial arrangement. Described by Rusydi (2008) that after inhabiting that houses, most Nglepen citizens did adjustment and adaptation of both physical and non-physical changes against the house and the surrounding environment. This is in accordance with the opinion of Rapoport (1969) which stated that the house is a structural form and its organization is influenced by the cultural environment that it possesses, and close relationship with the ways of life of its inhabitants. Moreover, residents' activities affect the space settings needed to accommodate the activities. Rapoport (1969) also identified that there are five aspects of the culture that is reflected in activities setting, namely; how to perform basic activities, family structure, gender roles, attitudes toward privacy and social processes. Further explained, culture influence and differentiate every activities system that occupies the space.

House form and the space inside is a reflection of residents' activity and their social life (Rusydi, 
2008). Rusyidi (2008) stated that residents must make adjustments and adaptations to accommodate not only the social activities but also activities that are personal. For the Indonesian, especially the Javanese community, social behavior is a culture that is rooted in societal life, that the house is the philosophy of not only includes the building but also social activities and the environment which represent the societal life (Tjahjono, 1989 in Syam, 2012). Social life reflected in the activities such as; arisan, gotong royong, sarasehan, rewang, tirakatan, etc., and these activities needed social space such as; terrace, living room, tritisan, courtyard and even the kitchen, that is not less important than functional space in the house. Social space conceived as a space that is formed for social activities (Asmal, et al., 2015). Shared space is part of social space that could be categorized as a public space, because it is used and is acknowledged by a group of people. The shared space is also interpreted as a communal space (Darmiwati, 2000) or a shared space (Prijotomo, J \& Pangarsa, GW 2010 in Indeswari, 2013). The occurrence of communal space in a settlement cannot be separated from an understanding of human interaction with their environment. There are some criteria of communal space (Lang, 1987), namely; the space in which people interact, space where people have joint activities and share, including social interaction, economic and culture with emphasis on the social activities; space held, managed and controlled together by both the public or private institution that is dedicated to the interests of the community;as public open space and visually and physically accessible for all; easy accessibility and visibility; and the space in which the people have the freedom to move (Lang, 1987; Indeswari, 2013; Darmiwati, 2000). Rapoport (1969) said that built environment is formed as functional space based on human activities and influenced by the setting or atmosphere of the environment, both physical and non-physical that directly influenced the activities pattern.

In dome house settlement in Ngelepen, behavioral adaptations performed by the residents because the existing house setting cannot accommodate their old habits, so they created a new setting in outer space to accommodate that activities. For most residents of the dome housing settlement, occupying the dome house that come from other cultures that different both in physical and spatial form, require them to do adaptation privately and socially. This adaptation can be observed through an understanding of how is the activity system of its inhabitants. By understanding how the inhabitants adapt to their dwellings, we can determine the extent to which the quality of life for residents will increase. Because by studying the adaptations made by residents through their system activity, we will understand what kind of activity that must be accommodated. Dome house Settlement in Nglepen, Yogyakarta was chosen as the location of these studies in view of the urgency to determine whether temporary or permanent housing assistance provided by the government with the support of foreign parties compatible and adaptable for the recipient. This study aims to identify the activity system formed in Nglepen dome house settlement with the intent to understand the improvement of the quality of life that would be obtained through the adaptation and adjustments made by occupants.

\section{METHODOLOGY}

The technique of data collection is obtained by observing the behavior (behavior mapping) of local residents' behavior on the outdoor space of their house as well as their neighborhood space. Questionnaires and interview were also taken with random sampling to confirm the things that are not observed and completed the information from the behavior mapping observation. The approach that is used to observe the behavior of the occupants of the dome house settlement through continuous place-centered behavior-mapping. This technique is used to know how the occupants use and accommodate their behavior in the specific time and place. The steps that were undertaken is as follows; 1) Decide the zone where the activities to be observed, 2) Categorize the types of activity that is to be observed, 3) Categorize the group of observed occupants activities based on gender, age, work, 4) Differentiate time settings (morning, day and night) with the types of activity and the type of occupants, 5) Categorize duration of time activities that occur.

The behavior mapping was carried out within 4 weeks observation in the morning, noon, evening and night. It is categorized based on 2 main groups, activity on the working days (weekday), Monday to Friday and on holidays (weekend), on Saturday and Sunday. Research samples categorized based on age group of residents that include children, adult women, adult male and elderly. The data is analyzed through categorization of behavioral mapping results and correlate it with grouping similar answers based on the results of the interview and questionnaires. The overall data analysis results are displayed in the form of a matrix, diagrams or patterns that shows the relationship between the behavior of the occupants and the space in forming of the communal space. 


\section{Research Area}

Dome house settlement in the village of Nglepen, Prambanan Temple is a relocated post disaster housing settlement that is allocated for the victims of the earthquake in Yogyakarta 2006 where most of the houses destroyed when the earthquake happened. It is located about $1 \mathrm{~km}$ from the old Nglepen original village. This new settlement consisted of 71 dome houses in the form of dome and circular floor plan. The dome house have two stories floor with a diameter of 7 meters wide and estimated about $38 \mathrm{~m}^{2}$.The settlement is divided into 6 cluster blocks consisted of 11-12 dome houses with communal space in the center for toilet and washing area. Neighborhood facilities include mosque, kindergartens, cemetery, clinic and open space. (Figure 1)

The dome house settlement development is constructed for 5 months starting 10 October 2006 and starts occupied by the end of April 2007. This area is the first project in Indonesia from World Association of Non-Govermental (WANGO) working with Domes for the World Foundation (DFTW) and the old monolithic Dome Institute (MDI) and was built by Dubai- based Emaar Properties.

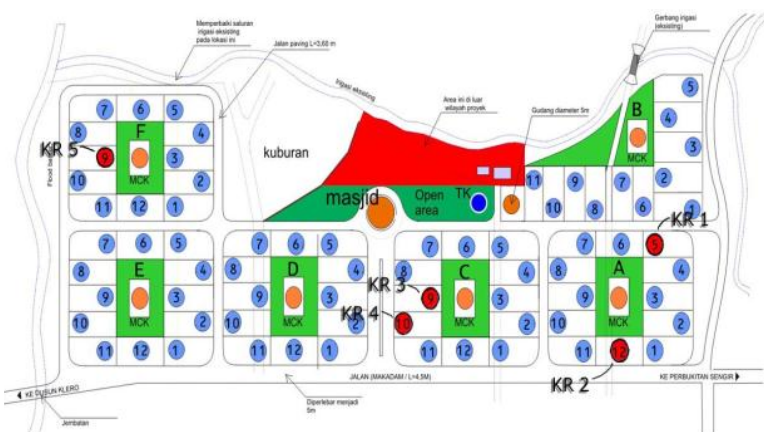

Fig. 1. Siteplan of Dome Settlement in Desa Nglepen, Yogyakarta

\section{RESULTS AND DISCUSSION}

Rapoport (1986) defines that the activity always contains 4 major points, namely; actors, kinds of activities, the place and duration of ongoing activities. The discussion of the types of activities undertaken by dividing the zones according to their utilization, namely; private zone, semi-private zone, semi-public zone and public zones. Private zone covering the room in the house, include bedroom, living room and kitchen. Semi-private zone is the space around the house, such as dome pathway and dome courtyard. Semi-public zone are the area used by the residents of dome settlement which include block communal, kindergarten, graveyard, open area, field, clinic, mushola, closed by facility, mushola, neigborhod street and corner street. Whereas, the settlement's main street included in the public zone.
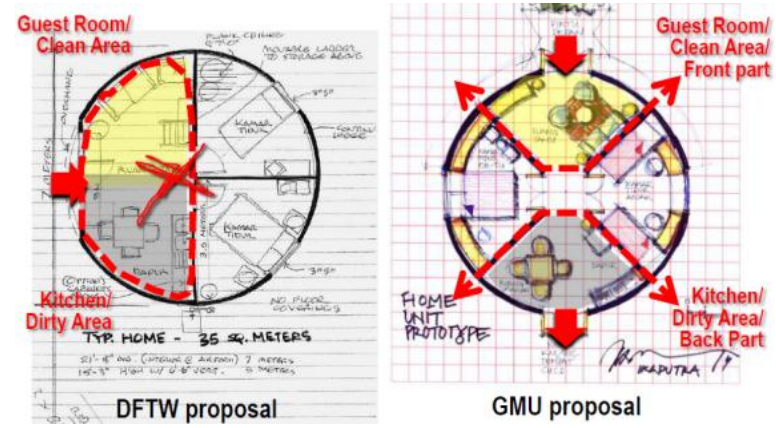

Fig. 2. Proposed house plans dome by DFTW (left) and the plan approved by the UGM (right)

Based on the initial concept, a house should be able to accommodate all the activities of its inhabitants, both personal or social activities. Unfortunately, in dome housing many activities that in previous house can be done inside the house now is being done outdoors because space is very limited. Research founding shows that the most prefered area for the occupants' to do activities that can not be done in the house are being done in zone semi-private (dome pathway and couryard) which accounted for $66 \%$. Meanwhile, other activities that related to interaction activities among dome's residents mostly performed in semi-public zone (31\%), which occurred in the shared space available on every block, kindergarten, mosque, courts, clinics and neighborhood streets. Other activities which are more common, involving many people and requires a larger space is done in the public zone, which is the settlement's main street(Figure 3).
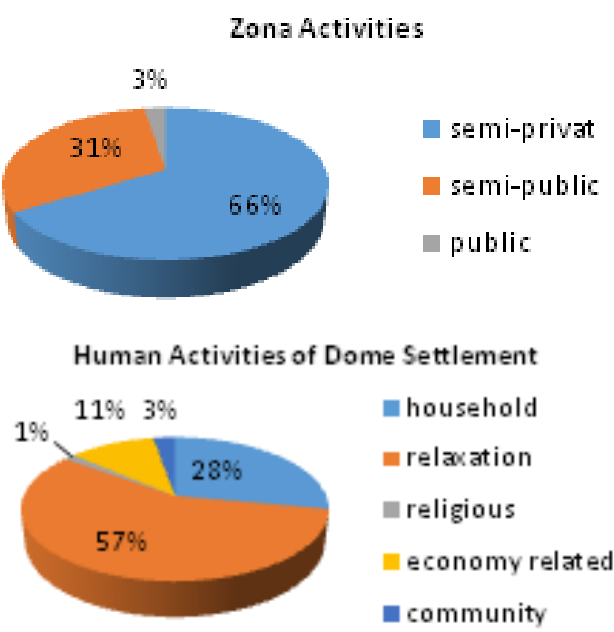

Fig. 3. Activity zone (left) and the type of activity (right) were residents of the dome house 


\section{Daily Community Activities}

Residents' daily activity are grouped into five main activities, namely; household activities, relaxation activities, religious activities, economic related activity and community activity. Findings shows that dome courdyard that is classified as semi-private zone mostly used as an extension of household activities (61.5\%). This condition occurred because many of household activities cannot be fully accommodated in the limited space of the house although some of the activities considered private. Relaxation activities (36.4\%) which took place in the same space is also considered personal activities that cannot be accommodated in the house. Pathways that supposedly use as walking area in fact use as area for relaxing activities (61.4\%) and household activities (23.6\%). This can occurred because pathway is directly connected to the house. Meanwhile, in the semipublic zone, especially in the communal blocks, types of activities occurred more varies (household activities $39.3 \%$, relaxation activities $28.6 \%$, and religious activities $25.0 \%$ ). These varieties happened considering the area is public that accommodate more people and have ease of accessibility and visibility. In public space, recreational activities dominate almost all space usage. These can be seen in the activities in kindergarten $(100 \%)$, open space $(71.2 \%)$, the area around the mosque $(87.5 \%)$, field $(68.2 \%)$, clinic (76.5\%) and the environment (38.5\%)(Table 1).

Table 2 shows that the area around the house is mostly used for personal activities. This happened because courtyards and pathways are directly connected to the house therefore became an extension space that can accommodate other activities of the occupants. Courtyard is mostly used for farming and gardening activities $(32.1 \%)$ as well as a children's play (20.7\%). The pathway are replacing the function of terrace that they had before where they are able to chat with neighbors (27.3\%), to observe the children running around and playing (39.9\%) or even to trade grocery shop (12.3\%). As describe before, 11-12 dome houses make a cluster unit that has a communal space and a shared toilet that can be accessed and

Table 1. The types of outdoor activities (in \%)

\begin{tabular}{|c|c|c|c|c|c|c|c|c|c|c|c|c|c|}
\hline Kind of activities & $\begin{array}{l}\text { Dome } \\
\text { courtyard }\end{array}$ & $\begin{array}{l}\text { dome } \\
\text { pathway }\end{array}$ & $\begin{array}{l}\text { block } \\
\text { commun } \\
\text { al }\end{array}$ & $\begin{array}{l}\text { kinder } \\
\text { garden }\end{array}$ & $\begin{array}{l}\text { open } \\
\text { area }\end{array}$ & mushola & field & clinic & $\begin{array}{l}\text { graveyar } \\
\text { d }\end{array}$ & $\begin{array}{l}\text { closed by } \\
\text { facility }\end{array}$ & $\begin{array}{l}\text { neighbor } \\
\text { hood st }\end{array}$ & corner st & $\begin{array}{l}\text { main } \\
\text { street }\end{array}$ \\
\hline household & $86(61.5)$ & $155(23.6)$ & 11(39.3) & $0(0.0)$ & $13(25.0)$ & $2(12.5)$ & $7(31.8)$ & $4(23.5)$ & ) 2(16.7) & $13(17.6)$ & $18(17.6)$ & $14(21.5)$ & $11(36.7)$ \\
\hline relaxation & $51(36.4)$ & $403(61.4)$ & $8(28.6)$ & $12(100)$ & $37(71.2)$ & $14(87.5)$ & $15(68.2)$ & $13(76.5)$ & $3(25.0)$ & $21(41.2)$ & $58(56.9)$ & $38(58.5)$ & $13(43.3)$ \\
\hline religious & $0(0.0)$ & $4(0.6)$ & $7(25.0)$ & $0(0.0)$ & $0(0.0)$ & $0(0.0)$ & $0(0.0)$ & $0(0.0)$ & $7(58.3)$ & $0(0.0)$ & $0(0.0)$ & $0(0.0)$ & $0(0.0)$ \\
\hline economy related & $1(0.7)$ & $85(13.0)$ & $0(0.0)$ & $0(0.0)$ & $0(0.0)$ & $0(0.0)$ & $0(0.0)$ & $0(0.0)$ & $0(0.0)$ & $17(33.3)$ & $11(10.8)$ & $11(16.9)$ & $5(16.7)$ \\
\hline community & $2(1.4)$ & $9(1.4)$ & $2(7.1)$ & $0(0.0)$ & $2(3.8)$ & $0(0.0)$ & $0(0.0)$ & $0(0.0)$ & $0(0.0)$ & $0(0.0)$ & $15(14.7)$ & $2(3.1)$ & $1(3.3)$ \\
\hline
\end{tabular}

Table 2. The relationship between the type of activity and the physical environment of the venue for the activity

\begin{tabular}{|c|c|c|c|c|c|c|c|c|c|c|c|c|c|c|c|}
\hline & & semi-p & rivate & & & & & semi-p & ublic & & & & & oublic & \\
\hline & Activities weekdays-weekends & 몬 & & $\overline{\text { लृ }}$ & & 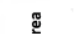 & & & & 홈 & & 号 & ज & ֻँّ & total $f(\%)$ \\
\hline & play with/take care children & $7(5.0)$ & $\therefore 01(15.4)$ & $4(14.3)$ & & $10(19.2)$ & $2(12.5)$ & $2(9.1)$ & $4(23.5)$ & $1(8.3)$ & $5(9.8)$ & $7(6.9)$ & $9(13.8)$ & & 152 \\
\hline & maintenance motorcycle/bicycle & $5(3.6)$ & $22(3.4)$ & & & & & & & & & $1(1.0)$ & 2(3.1) & & 30 \\
\hline & gardening/watering plants & $17(12.1)$ & $3(0.5)$ & $2(7.1)$ & & & & & & & & & & & 22 \\
\hline & cleaning yard,cleaning home & $7(5.7)$ & 10(1.5) & 1(3.6) & & $2(3.8)$ & & & & $1(8.3)$ & & & & & 21 \\
\hline & burning trash,throwing trash & $1(0.7)$ & & & & & & & & & & $1(1.0)$ & & & 2 \\
\hline household & farming for own self & $28(20.0)$ & $1(0.2)$ & & & & & $2(9.1)$ & & & & & & & 31 \\
\hline & cooking, make a fire, cutting wood,collecting wood & $4(2.9)$ & $5(0.8)$ & & & & & $1(4.5)$ & & & & & & & 10 \\
\hline & washing dishes & & $2(0.3)$ & & & & & & & & & & & & 2 \\
\hline & washing clothes, carpet & & $4(0.6)$ & $2(7.1)$ & & & & & & & & $1(1.0)$ & & & 7 \\
\hline & drying clothes/taking the dried clothes & $11(7.9)$ & $3(0.5)$ & 2(7.1) & & & & & & & & & & 2(6.7) & 18 \\
\hline & work (harvest,collecting grass,drying something, etc) & $6(4.3)$ & $4(0.6)$ & & & $1(1.9)$ & & $2(9.1)$ & & & $8(15.7)$ & $8(7.8)$ & $3(4.6)$ & $9(30.0)$ & 41 \\
\hline & take a rest(sunbathing,watching around,sit around/standing) & $5(3.6)$ & $35(5.3)$ & & $1(8.3)$ & $2(3.8)$ & $2(12.5)$ & $4(18.2)$ & & & $1(2.0)$ & $8(7.8)$ & 6(9.2) & $4(13.3)$ & 68 \\
\hline & take a rest (talking with each other) & $12(8.6)$ & 179(27.3) & 1(3.6) & $1(8.3)$ & 10(19.2) & 9(56.3) & $4(18.2)$ & $7(41.2)$ & $3(25.0)$ & 12(23.5) & 24(23.5) & $10(15.4)$ & $5(16.7)$ & 277 \\
\hline & take care of animals & & $2(0.3)$ & & & & & & & & & $1(1.0)$ & & & 3 \\
\hline & smoking, shaving, eating,washing face etc & $4(2.9)$ & 19(2.9) & & & & & & & & & $1(1.0)$ & & $1(3.3)$ & 25 \\
\hline relaxation & wi-fi-ing(browse internet),using phone & & $4(0.6)$ & & & $1(1.9)$ & & & $1(5.9)$ & & & & & & 6 \\
\hline & eat/drink & & $4(0.6)$ & & $2(16.7)$ & & & & 1(5.9) & & $1(2.0)$ & $1(1.0)$ & & $1(3.3)$ & 10 \\
\hline & parking & $1(0.7)$ & & & & & & & & & & & & & 1 \\
\hline & play around (children) & $29(20.7)$ & 160(24.4) & $7(25.0)$ & $8(66.7)$ & $21(40.4)$ & $3(18.8)$ & $6(27.3)$ & $4(23.5)$ & & $6(11.8)$ & $23(22.5)$ & $22(33.8)$ & $2(6.7)$ & 291 \\
\hline & play sports & & & & & $3(5.8)$ & & $1(4.5)$ & & & $1(2.0)$ & & & & 5 \\
\hline religiou & nyekar' & & & & & & & & & $7(58.3)$ & & & & & 7 \\
\hline rengous & wudhu & & $4(0.6)$ & $7(25.0)$ & & & & & & & & & & & 11 \\
\hline economy & purchase and sale street vendor & & $4(0.6)$ & & & & & & & & $3(5.9)$ & $11(10.8)$ & $11(16.9)$ & $5(16.7)$ & 34 \\
\hline related & purchase and sale at store (closing the shop) & $1(0.7)$ & $81(12.3)$ & & & & & & & & $14(27.5)$ & & & & 96 \\
\hline & meeting (tahlilan,rapat, gathering) & & $8(1.2)$ & & & & & & & & & & & & 8 \\
\hline community & remembrance) & & $1(0.2)$ & & & & & & & & & $14(13.7)$ & 2(3.1) & & 17 \\
\hline & kerja bakti'/ 'rewang' & $2(1.4)$ & & $2(7.1)$ & & $2(3.8)$ & & & & & & $1(1.0)$ & & $1(3.3)$ & 8 \\
\hline & & 140 & 656 & 28 & 12 & 52 & 16 & 22 & 17 & 12 & 51 & 102 & 65 & 30 & 1203 \\
\hline
\end{tabular}


used by residents in each cluster. Because the communal space is semi-public, various activities are also carried out in this such as supervise the children play (39.3\%) and wudhu(25.0\%). This condition of communal space is as described by (Lang, 1987), since the space is where people interact, have joint activities and share as well as the space held, managed and controlled together therefore it become a space that accessible for all member of the cluster which they have the freedom to move (Lang, 1987; Indeswari, 2013; Darmiwati, 2000).

\section{Time Setting of Activities}

Discussion of time setting is divided into three major groups, namely; morning time (8am to $11 \mathrm{am}$ ), daytime (11am to $4 \mathrm{pm}$ ) and evening (4pm to $7 \mathrm{pm}$ ). Based on observation shows that in the morning, the type of activities undertaken by children, adult man and woman tend to be balanced. In the mornings, the children $(28.5 \%)$ use outdoor space to play and run, while women $(27.7 \%)$ do household activities in courtyard or pathway that cannot be done in the house, while men $(33.8 \%)$ carry out activities outside the house or just relaxing. During noon, children' activities $(48.8 \%)$ is high considering school's hours were over and dome house didn't have adequate space to accommodate children's play activities, while the number of activities of the women (23.6\%) and men $(21.2 \%)$ tend to be similar. In the evening activities of the youth (38\%) and adult men (35\%) almost equal since many adult man has come back from work. Meanwhile, for elderly did not show significant activities, either in the morning (10\%), daytime (6.4\%) and night time (3\%). Most of the livelihood of adult men in this settlement are working in the informal sector while adult women are mostly housewives (Figure 4).

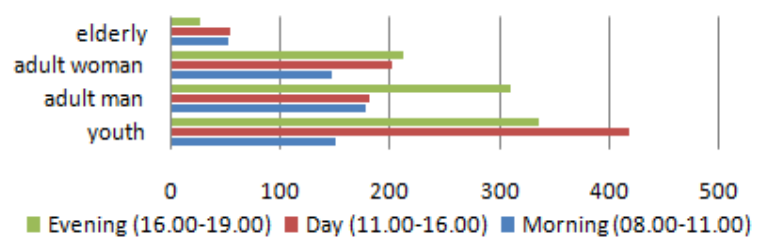

Fig. 4. Time setting based on actors

Based on the type of activities showed that in the morning, relaxing activities (50.9\%) and household activities $(31.5 \%)$ are the most observable activities. Similar situation also happen during daytime with relaxation activities $(56.4 \%)$ and household activities (25.4\%). Meanwhile during evening, relaxation activities increases (61.5\%) although household activities didn't changed much (28.4\%). Other activities, such as religious activities, activities related to economic and social activities both in the morning, noon and night did not reveal anything meaningful (Figure 5).

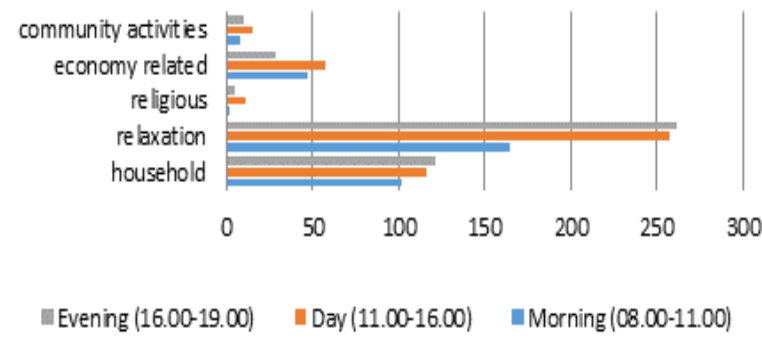

Fig. 5. Time setting based on types of activities

Highest activities observable are carried out on the dome pathway, whether it is done in morning (54\%), day (56.9\%) and night (48\%). Another activity is pretty much done as well on the neigborhood street (morning 11.8\%, day $16.2 \%$ and night 20.6\%) and in the field each home (morning 14.5\%, day $13.7 \%$ and night $13,9 \%$ ), while the other zones do not show significant activity.

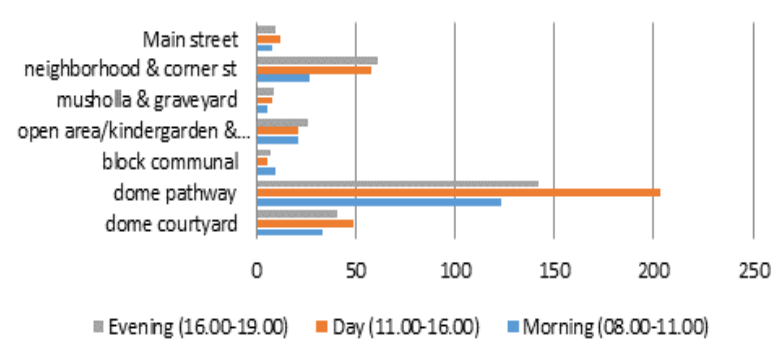

Fig. 6. Time setting based on place of activities

\section{Activities Setting on Weekdays and Weekends}

Weekdays and weekdays are observed because there are significant differences in the activities. For example, activities undertaken by male or female workers (working residents) and the tourist traffic increased in the area. There are similarities in the dominance of the use of outdoor space for activities which is the dome pathways area but there are differences in the number of users. On weekdays, the dome pathways used by the house around 277 activities (58.2\%) from the total of 476 activities, while on weekends activities used by 379 (52.1\%) and from a total of 727 activities. During weekdays, the dome courtyard used about 51 activities (10.7\%) and on weekends used by 89 activities (12.2\%). Meanwhile, other activities happened in almost all open space and public facilities in the dome house settlement. 
Table 3. Activities based on weekdays and weekends

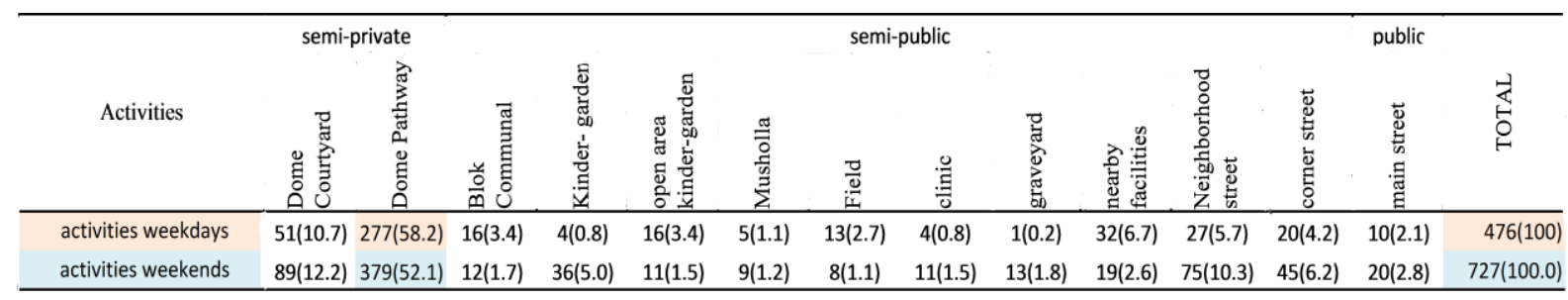

\section{CONCLUSION}

The results of this study showed that daily activities on weekdays and holidays conducted by different age groups; children, adult and elderly, at different areas and for different type of activities in certain times. The pathways and courtyard of the house mostly used for domestic household activities and leisure/ relaxation activities as an extension of the social interaction space that cannot be accommodated in the house. In understanding the system activities that occurred, it is expected that this study can contribute to improve the quality of life of people live in a relocation settlement.

\section{REFERENCES}

Asmal et al. (2015). Coastal Environmental Degradation U.S. Communal Space, Impact on Social Fishermen Community Life at North Galesong. Journal of innovation and research in Educational Sciences, 2(5). ISSN (online): 2349-5219.

Darmiwati, R. (2000). The study together in the space of housing for low-income residents. Journal Dimension, 28(2), p.114-122.

Hamilton-Baillie, B. (2008). The Shared Space: Reconciling People, Place and Traffic. Journal of the Built Environment, 34(2), p.161-181.

Indeswari, A. et. al. (2013). The pattern with the space on the settlement of the Madurese Medalungan in Hamlet Baran Randugading. Journal of the section, 11(1), p.37-46. ISSN 1693-3702.

Lang, J. (1987). Creating Architectural Theory. New York: Van Nostrand Reinhold Company.

Marcillia, S.R. \& Ohno, R. (2012). Amounts of Social Space in Self-Built and Donated Post Disaster Housing After Java Earthquake 2006. Asian Journal of Environment-Behavior Studies, 3(7), p. 25-34.

Oliver, P. (1987). Dwellings: The House across the world. Austin: University of Texas Press.

Purwanto, E. et. Al. (2012). The pattern of communal space in the Home Row Bandarharjo Semarang. Journal DIMENSI, 39(1), p.23-30. ISSN 0126219X.

Rusyidi, M. (2008). The behavior of the Companions of the house of the Dome in Prambanan, Sleman: Adaptation and Adjustment in the new settings. Journal of cross-space, 2(3), p.99-108. ISSN 1978-0702.

Rapoport, A. (1969). House, Form and Culture. Englewood Cliffs NJ: Prentice-Hall.

Rapoport, A. (1983). Culture and Change and Supportive Design. Pergamon Press: New York.

Saraswati, T. (2007). House Dome in Nglepen controversy, Prambanan, D.I. Yogyakarta. Journal DIMENSI, 32(2), p.136-142.

Zeisel, J. (1985). Inquiry by Design: Tools for Environment-Behavior Research. Cambridge, UK: Cambridge University Press. 